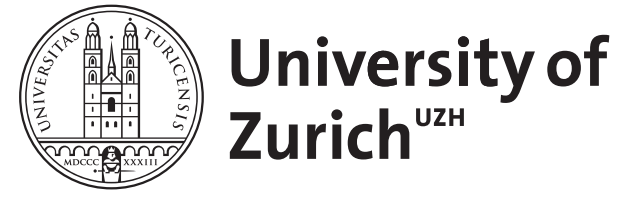

Zurich Open Repository and Archive

University of Zurich

University Library

Strickhofstrasse 39

CH-8057 Zurich

www.zora.uzh.ch

Year: 2017

Bottom-up constitutionalism: the case of net neutrality

Graber, Christoph Beat

DOI: https://doi.org/10.1080/20414005.2017.1300678

Posted at the Zurich Open Repository and Archive, University of Zurich

ZORA URL: https://doi.org/10.5167/uzh-202964

Journal Article

Originally published at:

Graber, Christoph Beat (2017). Bottom-up constitutionalism: the case of net neutrality. Transnational Legal Theory, 7(4):524-552.

DOI: https://doi.org/10.1080/20414005.2017.1300678 


\section{Bottom-up constitutionalism: the case of net neutrality}

\section{Christoph B. Graber}

To cite this article: Christoph B. Graber (2016) Bottom-up constitutionalism: the case of net neutrality, Transnational Legal Theory, 7:4, 524-552, DOI: 10.1080/20414005.2017.1300678

To link to this article: http://dx.doi.org/10.1080/20414005.2017.1300678

曲 Published online: 21 Mar 2017.

Submit your article to this journal $₫$

Q View related articles $₫$

View Crossmark data ־ 


\title{
Bottom-up constitutionalism: the case of net neutrality
}

\author{
Christoph B. Graber ${ }^{a, b}$

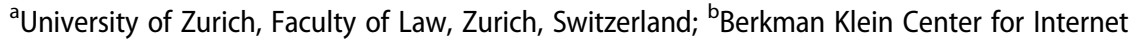 \\ and Society, Harvard University, Cambridge, MA, USA
}

\begin{abstract}
Net neutrality is no longer only a battle cry of a few Internet romancers but has evolved into a key value for contemporary society that is being institutionalised as a constitutional right. With the help of sociological systems theory, this text argues that the social and legal institutionalisation of constitutional rights need to be distinguished. Commonly, constitutional rights emerge from society before they are reformulated in the legal realm. Using the example of the United States, the paper shows empirically that net neutrality is about to emerge as a new fundamental value and right. Its constitutionalisation is happening bottom-up, driven by social movements, Internet activists and advocacy groups, and further, in an interweavement of civil society dynamics with the legal system. The question is whether constitutional structures have already become identifiable. The last section discusses the relationship between social and formal constitutional structures from a legitimacy and democracy perspective.
\end{abstract}

KEYWORDS Transnational constitutionalism; digital networks; net neutrality; legal sociology; sociological systems theory

\section{Introduction}

On 26 February 2015 the Federal Communications Commission (FCC) adopted new rules on net neutrality, requiring providers of fixed and wireless Internet access to respect the principle of Internet openness and to abstain from blocking, throttling or paid prioritisation practices. ${ }^{1}$ Considering the long history of unsuccessful campaigning for net neutrality in the United States, this was quite a spectacular result. ${ }^{2}$ Originally, network neutrality was coined by Timothy Wu in 2003 as a political term identifying the maintenance of the openness and freedom of the Internet architecture as a public

\section{CONTACT Christoph B. Graber christoph.graber@rwi.uzh.ch}

${ }^{1}$ See Federal Communications Commission, 'Protecting and Promoting the Open Internet, FCC Report and Order on Remand, Declaratory Ruling, and Order', GN Docket No 14-28, FCC 15-24, adopted 26 February 2015, 7-8.

${ }^{2}$ On the origins and history of the net neutrality debate in the US see Jeffrey A Hart, 'The Net Neutrality Debate in the United States' (2011) 8(4) Journal of Information Technology \& Politics 418. 
policy goal. ${ }^{3}$ In 2008, the FCC made its first attempt to turn network neutrality into a legal concept when deciding that Comcast was not allowed to one-sidedly throttle content that originated from peer-to-peer platforms. Two years later the FCC's decision was reversed by the Court of Appeals for the District of Columbia (DC) Circuit, based on the argument that the FCC's regulation lacked the necessary legal basis. ${ }^{4}$ In reaction to that decision, the FCC back-pedaled and announced new rules on 21 December 2010, allowing Internet service providers (ISPs) to engage in traffic management policies provided they were transparent and did not involve 'unreasonable discrimination'. ${ }^{5}$ Although these rules were only 'better-than-nothing' and frustrated expectations of comprehensive net neutrality prohibiting any discrimination between data packages, ${ }^{6}$ they were again struck down by the Court of Appeals for the DC Circuit in Verizon v FCC on 14 January 2014. ${ }^{7}$ Again, the lack of a sufficient legal foundation for the FCC regulation was the main reason for the court's verdict. ${ }^{8}$ Considering this second defeat of the Commission for its open Internet regulatory politics, it was quite surprising that only one year later the FCC had adopted an order paving the way for the fully fledged institutionalisation of net neutrality grounded on a solid basis in US law. How has this been possible?

The thesis to be presented and defended in this paper is that the FCC has been able to do this because the call for net neutrality is no longer only a battle cry of a few Internet romancers but has evolved into a key value for contemporary society, a value that is being institutionalised as a constitutional right. The paper's theoretical foundation is sociological systems theory as developed by Niklas Luhmann and others. On these grounds it will argue that the social institutionalisation of constitutional rights is to be distinguished from their legal institutionalisation. Commonly, constitutional rights emerge from society before they are reformulated in the legal realm. The paper intends to prove empirically that net neutrality is about to emerge as a new fundamental value and it does so because of its supreme importance for the protection of free and open communication processes on the Internet. Although this is a global development, the paper's empiric focus is primarily on the United States. The constitutionalisation of net neutrality is happening bottom-up, driven by social movements, Internet activists and advocacy groups, and, in

\footnotetext{
${ }^{3}$ Timothy Wu, 'Network Neutrality, Broadband Discrimination' (2003) 2 Journal on Telecommunications and High Technology Law 141.

${ }^{4}$ Comcast v FCC (6 Apri1 2010) USCA 08-1291 (DC Circuit).

${ }^{5}$ Federal Communications Commission, 'Preserving the Open Internet, 25 FCC Rcd 17905 and FCC Report and Order', GN Docket No 09-191,WC Docket No 07-52, FCC 10-201, adopted 21 December 2010.

${ }^{6}$ Harold Feld, 'Quick Guide Upcoming Net Neutrality Rules Challenge', Public Knowledge (23 September 2011), online: <www.publicknowledge.org/news-blog/blogs/quick-guide-upcoming-net-neutralityrules-cha>.

${ }^{7}$ Verizon v FCC (14 January 2014) USCA 11-1355 (DC Circuit).

${ }^{8}$ Adi Robertson, 'Federal Court Strikes Down FCC Net Neutrality Rules', The Verge (14 January 2014), online: <www.theverge.com/2014/1/14/5307650/federal-court-strikes-down-net-neutrality-rules>.
} 
a second step, an interweavement of such civil society dynamics with the legal system. A further question to be addressed will be: have we already reached the point where constitutional structures become identifiable? In the last section the paper discusses the relationship between social and formal constitutional structures from a legitimacy and democracy perspective.

\section{Legal and sociological constitutional theorising}

\subsection{What is a constitution?}

The key question that needs to be addressed in this paper as a preliminary is: what is a 'constitution' and how should we conceive this concept in the digital networked environment?

In the context of public law doctrine and also in everyday language, the word 'constitution' is commonly used to refer to a written text containing a set of rules and principles that are of fundamental importance for a nation state. There is general agreement that the term constitution originally related to the nation state. ' According to Harold Berman, the term 'constitutionalism' was invented around the threshold of the nineteenth century 'to refer chiefly to the American doctrine of supremacy of the written constitution over enacted laws'. ${ }^{10}$ Processes of generalised legal formalisation already existed in the high medieval European society. However, as pointed out by Chris Thornhill, this involved little more than the establishment of formally drafted summaries of existing common laws or customs'. ${ }^{11}$ The subsequent period of early modernity witnessed an increasing (albeit heterogeneous) positivisation of the law and a simultaneous expansion of political abstraction. ${ }^{12}$ However, constitutions as formalised texts were only adopted at the end of the eighteenth century. ${ }^{13}$ Formalised constitutions emerged at that time in the United States and in France as a consequence of revolutions against a monarchic dominion that had claimed to be independent of the law. To clearly distance the revolutionary project from the old regime, a written document of law was required that regulated the establishment and exercising of state power. ${ }^{14}$ Consequently, a constitution in the

\footnotetext{
${ }^{9}$ Dieter Grimm, 'Constitution beyond the Nation State?' (2011) Zeitschrift für Rechtssoziologie 181, 181.

${ }^{10}$ Harold J Berman, Law and Revolution (Harvard University Press, 1983) 396.

${ }^{11}$ Chris Thornhill, A Sociology of Constitutions: Constitutions and State Legitimacy in Historical-Sociological Perspective (Cambridge University Press, 2011) 57-58.

12 This evolution was boosted by the Reformation in evangelical societies but evolved differently in most post-Reformation territories. A level of statehood that is comparable to modern legal and political autonomy had not been achieved in the sixteenth and seventeenth centuries (see Thornhill ( $n$ 11) 96-103, 158-9).

13 Thornhill considers the fact that 'laws were increasingly written in textual form' to be an important parameter in a general development towards political abstraction and legal generalisation (Thornhill (n 11) 74).

${ }^{14}$ Grimm (n 9) 181.
} 
formal sense can be defined as a supreme text of political and legal nature that constitutes and limits the power of the state. ${ }^{15}$

Mostly as a consequence of the establishment of an international legal order and fuelled by the effects of globalisation, we have been experiencing a growing interest in the legal literature surrounding the question of whether the concept of the constitution could also have a meaning beyond the borders of the nation state. ${ }^{16}$ This question is of particular importance for the topic of this paper since the Internet is a global medium, and studying the relationship between net neutrality and constitutionalism thus requires a global perspective.

With regard to the debate on how it would be possible to conceptualise constitutionalism beyond national territorial borders, one can distinguish between two main schools of thought. First, there is classical legal literature surrounding the question of a possible 'constitutionalisation of international law. ${ }^{17}$ According to these views, international law in the aftermath of the Second World War is perceived as a stratified system of different interrelated and mutually supportive legal orders with a constitution at its top which is represented by the Charter of the United Nations. ${ }^{18}$ A similar discussion takes place at the mega-regional level, related to the economic and political integration of the European Union (EU) and the crucial role that the Court of Justice of the EU (CJEU) has been performing in this process of 'constitutionalisation'. ${ }^{19}$ A key question here is the relationship between the primarily economic freedoms enshrined in the Treaty on the Functioning of the EU and the Charter of Fundamental Rights of the EU, and the rights guaranteed in the national constitutions of EU member states as well as in the standard-setting

\footnotetext{
${ }^{15}$ Thornhill (n 11) 8-11.

${ }^{16}$ For sceptical views see Grimm (n 9); Dieter Grimm, 'The Achievement of Constitutionalism and Its Prospects in a Changed World' in Petra Dobner and Martin Loughlin (eds), The Twilight of Constitutionalism? (Oxford University Press, 2010) 3-22; Martin Loughlin, 'What is Constitutionalism?' in Petra Dobner and Martin Loughlin (eds), The Twilight of Constitutionalism? (Oxford University Press, 2010) 47-72; Martin Loughlin and Neil Walker (eds), The Paradox of Constitutionalism: Constituent Power and Constitutional Form (Oxford University Press, 2007).

${ }^{17}$ Oliver Diggelmann and Tilmann Altwicker, 'Is There Something Like a Constitution of International Law?: A Critical Analysis of the Debate on World Constitutionalism' (2008) 68 Zeitschrift für ausländisches öffentliches Recht und Völkerrecht 623; Anne Peters, 'Are we Moving towards Constitutionalization of the World Community?' in Antonio Cassese (ed) Realizing Utopia. The Future of International Law (Oxford University Press, 2012) 118-35. For an overview of the literature see Jan Klabbers, Anne Peters and Geir Ulfstein, The Constitutionalisation of International Law (Oxford University Press, 2009); and Thomas Kleinlein and Anne Peters, 'International Constitutional Law' in Anthony Carty (ed), Oxford Bibliographies in International Law (Oxford University Press, 2013).

${ }^{18}$ See Bardo Fassbender, The United Nations Charter as the Constitution of the International Community (Nijhoff, 2009); Bardo Fassbender, "'We the Peoples of the United Nations": Constituent Power and Constitutional Form in International Law' in Neil Walker and Martin Loughlin (eds), The Paradox of Constitutionalism. Constituent Power and Constitutional Form (Oxford University Press, 2007) 269-90; Erika De Wet, 'The International Constitutional Order' (2006) 55 International \& Comparative Law Quarterly 51.

19 Joseph HH Weiler, The Constitution of Europe: 'Do the New Clothes have an Emperor?' and other Essays on European Integration (Cambridge University Press, 1999).
} 
human rights instruments at the European and global level. ${ }^{20}$ This literature, however, remains caught in narrow frames of public law and political philosophy, tending to extrapolate constitutional thinking from the nation state to the global or regional level. ${ }^{21}$

Second, there is literature addressing the topic of constitutionalism from a sociological perspective, while keeping its focus on politics and the state. Whereas the first (essentially legal) type of constitutional theorising is, as mentioned above, mostly interested in the form of the constitution, this sociological approach uses the term constitution to relate to its necessary functions in constituting and balancing the political system and the legal system. Hence, the formal-normative perspective on the constitution that is common ground in the legal literature is juxtaposed by a functional-empirical one. Niklas Luhmann has contributed pioneering work analysing the evolution of nation states' formal constitutions from a functional perspective of sociological systems theory as the close structural coupling of the legal and political systems. ${ }^{22}$ Accordingly, the constitution of a nation state has a double existence, as both a supreme text of legal authority and as the political foundation of a society.

A functional perspective suggests distinguishing constitutive and limitative structures or functions in the existing formal constitutions. The constitutive and limitative functions have evolved over a long historical process and they first became visible at the end of the Middle Ages with the development of a degree of political or legal autonomy and, as a pendency of emerging statehood, the restriction of personal and sectoral privileges. ${ }^{23}$ In a modern formal constitution, the constitutive function is generally anchored in its chapters regulating the organisation and government of the legislative, executive and judicial powers. The limitative function can be identified in those parts of a formal constitution where the fundamental rights of citizens are guaranteed. It can also be found in the system of checks and balances that orders the mutual relationship between the legislative, the executive and the judicial powers and, in federal states such as Switzerland, the relationship between the federal and the sub-federal levels of government.

\footnotetext{
${ }^{20}$ See Dierk Schindler, Die Kollision von Grundfreiheiten und Gemeinschaftsgrundrechten: Entwurf eines Kollisionsmodells unter Zusammenführung der Schutzpflichten- und Drittwirkungslehre (DunckerHumblot, 2001).

${ }^{21}$ See the discussion in Gunther Teubner, 'The Project of Constitutional Sociology: Irritating Nation State Constitutionalism' (2013) 4 Transnational Legal Theory 44, 52. Theoretically, these writings are often directly or indirectly influenced by Hans Kelsen's 'pure theory of law' (Pure Theory of Law, translation from the second revised and enlarged German edition by M Knight, (University of California Press, 1970) ch 7). See eg Chris Thornhill, 'The Mutation of International Law in Contemporary Constitutions: Thinking Sociologically about Political Constitutionalism' (2016) 79(2) The Modern Law Review 207, 2089.

22 Niklas Luhmann, 'Verfassung als evolutionäre Errungenschaft' (1990) 9 Rechtshistorisches Journal 176; Niklas Luhmann, Die Politik der Gesellschaft (Suhrkamp, 2000) 391-2.

${ }^{23}$ Thornhill (n 11) 80.
} 
Luhmann's writings have greatly influenced later work on sociological constitutionalism focusing on the question of whether functional equivalents of the constitutive and limitative functions of a nation state constitution could be identified in or extended to the international legal and political order. ${ }^{24}$

\subsection{For a transnational concept of constitution}

As the impact of net neutrality exceeds the territorial boundaries of nation states and considering the fact that a few private actors have become extremely powerful on the Internet, Niklas Luhmann's view of today's society as a world society ${ }^{25}$ is of the greatest interest to the study of constitutionalism on the Internet. For Luhmann, world society stands for a world of globalised functional societal differentiation. Accordingly, the emergence of constitutional functions cannot be analysed in the national realm only, but the perspective must be extended to a global horizon. The principle of functional societal differentiation is commonly understood as the embodiment of modernity. ${ }^{26}$ Luhmann's thesis that the transition to functional differentiation 'can culminate only in the establishment of a world societal system ${ }^{27}$ prompted one strand of constitutional sociology to acknowledge that constitutions may evolve in transnational political processes outside the nation state. ${ }^{28}$

In the world society, most function systems of society spread globally, including the economy, science, art, education, health, mass media and family (to list the systems Luhmann mentions most frequently). Regarding the systems of law and politics, the situation is more complicated. While territorial differentiation continues to be important for the law, ${ }^{29}$ the reach of the legal system has expanded to also include elements of international, transnational and global law. By contrast, the political system remains strongly centred in the nation state. For Luhmann ' $\mathrm{t}$ ] he result is that the structural coupling of the political system and the legal system through constitutions does not have an equivalent at the level of global society'. ${ }^{30}$ As a consequence, the asymmetry between politics and law at the global level reflects a decline of constitutionalism.

\footnotetext{
${ }^{24}$ For a recent account see Thornhill (n 21).

${ }^{25}$ Niklas Luhmann, Theory of Society, vol I, translated by Rhodes Barret (Stanford University Press, 2012) 83-99; Niklas Luhmann, Die Politik der Gesellschaft (Suhrkamp, 2000) 220.

${ }^{26}$ The scholars most influential in conceptualising theories of societal differentiation have been Emile Durkheim, Georg Simmel, Max Weber, Talcott Parsons, Pierre Bourdieu and Niklas Luhmann.

27 Niklas Luhmann, Theory of Society, vol II, translated by Rhodes Barret (Stanford University Press, 2013) 129.

28 Teubner (n 21) 45.

${ }^{29}$ The reason for the law to remain partly differentiated territorially is that the court system (a sub-system of the law) is organised at the national level. See Niklas Luhmann, Theory of Society, vol I, (n 25) 96.

${ }^{30}$ Niklas Luhmann, Law as a Social System, translated by Klaus Alex Ziegert (Oxford University Press, 2004) 487-8. See also Gunther Teubner, "'Global Bukowina": Legal Pluralism in the World Society' in Gunther Teubner (ed), Global Law Without a State (Dartmouth, 1997) 3-28, 6.
} 
Analysing the question from a different perspective, a new thrust of sociological constitutional thinking has emerged that is mainly known as civil or societal constitutionalism. This is a strand of constitutional sociology that studies the emergence of constitutions outside international politics in the global society's 'private' sectors. ${ }^{31}$ A leading scholar of societal constitutionalism is David Sciulli, who laid the foundations for his theory more than 20 years ago. ${ }^{32}$ For Sciulli, voluntary procedural restraints in the economy or other spheres of society question the presupposition of a demise of constitutionalism. Following up on Sciulli's thesis, Gunther Teubner's approach to societal constitutionalism is to reconstruct the central functions of a constitution in a world society that has been shifting from territorial differentiation to functional differentiation. ${ }^{33}$ Teubner observes the evolution of constitutional norms in a variety of transnational contexts ${ }^{34}$ while showing a particular interest in the analysis of constitutional processes in the digital environment ${ }^{35}$ and in the economic sphere. ${ }^{36}$ One of the main questions in his research relates to the role and constitutional status of transnational corporations (TNCs), as some of them have become so powerful that they challenge the governance of nation states in a number of respects. ${ }^{37}$ TNCs have constituted themselves as new actors of the world economy in order to release themselves from the influence of national legal orders. They benefit from the strong competition between states to attract powerful corporations as providers of jobs and as tax payers. TNCs are thus free to establish themselves in the state that offers the most favourable legal conditions for business and-in cases of political change or other reasons-to move their domicile from one country to another.

For Teubner, TNCs operate in the organised professional sphere of the economic system. At a micro-level he argues that TNCs develop their own constitutions, distinguishing internally between constitutive and limitative functions. While the constitutive functions in TNC constitutions are strongly

\footnotetext{
31 Teubner (n 21) 45.

32 David Sciulli, Theory of Societal Constitutionalism: Foundations of a Non-Marxist Critical Theory (Cambridge University Press, 1992); see also David Sciulli, Corporate Power in Civil Society: An Application of Societal Constitutionalism (New York University Press, 2001).

${ }^{33}$ Gunther Teubner, 'Societal Constitutionalism: Alternatives to State-Centred Constitutional Theory?' in Christian Joerges et al (eds), Transnational Governance and Constitutionalism (Hart, 2004) 3-28; Gunther Teubner, Constitutional Fragments: Societal Constitutionalism and Globalization, translated by Gareth Norbury (Oxford University Press, 2012). For a critical appraisal see Karl-Heinz Ladeur, 'The Evolution of the Law and the Possibility of a "Global Law" Extending Beyond the Sphere of the State-Simultaneously, a Critique of the "Self Constitutionalisation" Thesis' (2012) Ancilla luris 220.

34 Teubner (n 21) 46-51.

35 Teubner, 'Societal Constitutionalism' (n 33).

${ }^{36}$ Gunther Teubner, 'Transnational Economic Constitutionalism in the Varieties of Capitalism' (2015) 0102 The Italian Law Journal 219.

${ }^{37}$ Gunther Teubner, 'Self-Constitutionalizing TNCs? On the Linkage of "Private" and "Public" Corporate Codes of Conduct' (2011) 18(2) Indiana Journal of Global Legal Studies 17; see also Chris Thornhill, A Sociology of Transnational Constitutions: The Social Foundations of the Post-National Legal Structure (Cambridge University Press, 2016), chapter 7.
} 
institutionalised, the limitative functions are underdeveloped. Teubner's question-which is also of importance in the realm of this paper-is how TNCs can be 'pushed' to develop limitative functions in their constitutions. ${ }^{38}$ For Teubner, such pressure can only arise from segments of civil society, such as labour unions, consumer protection organisations, activist movements, etc. ${ }^{39}$

Societal constitutionalism therefore is highly relevant for this paper, particularly the perspective of Teubner. In cyberspace we are in the presence of powerful TNCs including Google, Apple, Facebook and Amazon or big Internet access providers such as Comcast that-sometimes in cooperation with public actors-are creating hybrid worlds of governance that deeply impact the rights and freedoms of citizens. This development raises important questions including: (1) How can constitutional or human rights disciplines be extended to such players, which-as private actors-are not subjects of international law and are not bound by nation state constitutional law; (2) Is it possible to tame the power of big Internet companies by means of constitutional rights? These questions go beyond the scope of this paper and are the subject of an ongoing research project of the author.

\section{The emergence of net neutrality as a new constitutional value}

\subsection{Social change and constitutional alteration}

Different legal orders have developed different answers to the question of how the reality of social change should be associated with the idea of constitutional stability. Most Western jurisdictions provide for specific rules regulating how the formal constitution of a nation state can be altered. According to HLA Hart, in the course of modernisation legal systems have developed secondary rules to supplement primary rules of obligation that alone cannot cope with enhanced societal complexity. ${ }^{40}$ Among the secondary rules distinguished by Hart, a rule of change will serve to remedy the static quality from which the normative order of a society would suffer if consisting only of primary rules of obligation. ${ }^{41}$ Rules of change can refer to the alteration of both ordinary legislation and the formal constitution. ${ }^{42}$ Generally, an alteration to a

\footnotetext{
${ }^{38}$ Teubner, Constitutional Fragments (n 33) 75-88.

39 lbid.

40 HLA Hart, The Concept of Law (Clarendon Press, 1961) 89.

${ }^{41}$ According to Hart, a normative order with a static quality does not possess the means 'of deliberately adapting the rules to changing circumstances, either by eliminating old rules or introducing new ones' (Hart (n 40) 90).

42 The alteration of the formal constitution needs to be distinguished from its 'evolutive' or 'dynamic' interpretation through the judiciary. Such practices will most often unfold within a 'grey zone' that is not explicitly regulated in the formal constitutional text and is likely to cause controversial reactions including allegations of 'judicial activism'. On evolutive interpretation of the US constitution from a comparative perspective see Kanstantsin Dzehtsiarou and Conor O'Mahony, 'Evolutive Interpretation of Rights Provisions: A Comparison of the European Court of Human Rights and the U.S. Supreme Court' (2013) 44(2) Columbia Human Rights Law Review 309.
} 
formal constitution will need to meet procedural requirements that are stricter than those governing the alteration of ordinary legislation. ${ }^{43}$ Whereas certain jurisdictions do not distinguish between types of constitutional rules, ${ }^{44}$ other jurisdictions do not allow for the alteration of guarantees of democratic government or the rule of law.

In Switzerland, the Federal Court has been adding unwritten fundamental rights to the texture of the formal constitution since $1959 .{ }^{45}$ In its case law related to the Swiss Federal Constitution of 1874, the Swiss Federal Court has recognised a number of legally binding and enforceable fundamental rights, notwithstanding the absence of a direct point of reference in the formal constitutional document. ${ }^{46}$ Among these fundamental rights are the right to own property, the freedom of expression, the right to personal freedom, the freedom of assembly, the freedom to use any language and the right to assistance and care. On the occasion of the total revision of the Swiss Constitution in 1999, these rights were all formally included in the revised constitutional document. The possibility for the Swiss Federal Court to recognise unwritten fundamental rights when necessary also continues to exist under the new Constitution of 1999. ${ }^{47}$

From a sociological perspective the practice of recognising unwritten fundamental rights by court decision can be explained as a legal institutionalisation of an important value that has so far only been socially institutionalised. According to Niklas Luhmann, this reflects that fundamental rights are first and foremost social institutions. ${ }^{48}$ Thus, fundamental rights as we find them in formalised nation state constitutions are reformulations of fundamental social values in the 'language' of the legal system. With the recognition of an unwritten fundamental right the judiciary can decide to supplement the existing catalogue of fundamental rights, as a response to perceived changes in the social or technological reality.

In Switzerland, it was Zaccaria Giacometti, in 1955, who theoretically paved the way for recognition of unwritten fundamental rights by the Swiss Federal Court. ${ }^{49}$ Giacometti was of the view that it is the essence and axiomatic principle of fundamental rights to provide for a comprehensive

\footnotetext{
${ }^{43}$ The Constitution of the United States provides for the possibility of constitutional amendment in Article $\mathrm{V}$. The amendment process is divided into two stages, a proposal of amendment and its subsequent ratification. Both steps require a supermajority consensus. These relatively strict requirements for constitutional alteration may explain why the US Constitution has only rarely been amended since it was adopted (Laurence Tribe, American Constitutional Law (Foundation Press, 3rd edn 2000) 94-95).

${ }^{44}$ See Articles 192-5 of the Federal Constitution of the Swiss Confederation of 18 April 1999.

${ }^{45}$ See René A Rhinow and Markus Schefer, Schweizerisches Verfassungsrecht (Helbing Lichtenhahn, 2nd edn 2009) 201.

46 lbid, 5.

47 Ibid, 201.

${ }^{48}$ Niklas Luhmann, Grundrechte als Institution: Ein Beitrag zur politischen Soziologie (Duncker \& Humblot, 1965) 13.

49 Zaccaria Giacometti, 'Die Freiheitsrechtskataloge als Kodifikation der Freiheit: Festrede des Rektors Zaccaria Giacometti, gehalten an der 122. Stiftungsfeier der Universität Zürich am 29. April 1955', in Jahresbericht der Universität Zürich 1954/1955, 3-24.
} 
guarantee of individual freedom and human dignity in the context of the state. ${ }^{50} \mathrm{He}$ emphasised that his understanding of fundamental rights was positivistic and not metaphysical or political. ${ }^{51}$ The catalogue of fundamental rights existing in a formal written constitution can only include those articulations of human freedom that were known to be endangered at the time when the historic constitution-maker was at work. Since time passes and social conditions change, 'every new aspect of individual freedom that receives clear form as a consequence of new interferences with human dignity or individual personality must also be guaranteed by the catalogue of human rights'. ${ }^{52}$ Since the possibility of state intrusions on individual freedom seems factually unlimited, consequently the enumeration of fundamental rights in a formal constitutional document also cannot be exhaustive. In support of his theory Giacometti also mentioned the Ninth Amendment of the US Constitution, stating that 'the enumeration in the Constitution, of certain rights, shall not be construed to deny or disparage others retained by the people. ${ }^{53}$

Constitutional alteration by the judiciary is not unproblematic since it interferes with the separation and division of powers that is itself one of the cornerstones of the rule of law. The Swiss Federal Court is aware of the problem since historically it has recognised new fundamental rights only in situations of pressing social need and provided that certain formal requirements are met. For example, when the Court recognised the freedom of expression in 1965, it considered-under the influence of Giacometti-that this freedom was a necessary precondition for the freedom of the press, which was explicitly provided by the written constitution. ${ }^{54}$ In addition, the Swiss Federal Court considered that, at the time, freedom of expression was explicitly guaranteed by several constitutions of Swiss Cantons.

\subsection{Normative contours of a new constitutional right}

Is net neutrality a fundamental social value that, although not contained in formalised constitutional documents, should be legally recognised as a binding and enforceable constitutional guarantee? This is a normative question. It would probably not make much sense to answer it in the abstract and without taking account of particular national rules regulating procedures of constitutional alteration. Methodologically, an exemplary approach may thus be sensible, exploring the problem in light of the criteria for the recognition of unwritten fundamental rights discussed above as developed by the

\footnotetext{
${ }^{50}$ Ibid, 18.

51 Ibid, 8.

52 lbid, 17 (translation by the author).

53 lbid, 21.

54 Swiss Federal Court Decision BGE 91 I 480, at p 485; see Peter Saladin, Grundrechte im Wandel (Stämpfli, 3rd edn 1982) 75 and Jörg Paul Müller, Die Grundrechte der schweizerischen Bundesverfassung. Grundrechte besonderer Teil (Stämpfli, 2nd edn 1991) 89.
} 
Swiss Federal Court. According to this practice, an important social change would first be required as a precondition.

This important social change has been the rise of new technologies which has enabled the digital networked environment to become the primary platform of communication in developed societies. According to the European Court of Human Rights (ECtHR), today the Internet is one of the principal means for individuals to exercise their freedom of expression and information as guaranteed under Article $10 \mathrm{ECHR}$, and it is there that 'one finds essential tools for the participation in activities and debates related to questions of politics or public interest'. ${ }^{55}$ According to settled case law of the ECtHR, Article 10 ECHR covers not only the content of information but also the means of dissemination of such information. ${ }^{56}$ In Cengiz $v$ Turkey, the ECtHR found in 2015 that the imposition of a blanket blocking order on access to YouTube by the Turkish authorities violated the rights of the applicants under Article 10 ECHR. Although the applicants were not directly targeted by the measure, the blocking order had affected their right under Article 10 ECHR since YouTube was an important means for them to exercise their right to receive and impart information or ideas. ${ }^{57}$ For similar reasons the ECtHR had already decided in Ahmet Yildirim $v$ Turkey that the general blocking of the Google search engine violated Article 10 ECHR ${ }^{58}$ In both cases the applicable Turkish Law no 5651 did not allow the judicial authorities to impose a blanket blocking order on access to the mentioned websites. In Cengiz v Turkey, Law no 5651 was amended during pending proceedings and now allows, under certain conditions, blocking orders to be imposed on an entire website. Since the case had to be adjudicated on the facts given when the application was filed, the Court did not decide whether such a broad blocking order would be in conformity with Article 10 ECHR. The ECtHR noted however, obiter, that any blocking order must respect strict requirements regarding its delimitation, and efficient mechanisms of judicial review must be provided. ${ }^{59}$

As the prohibition on blocking Internet access is one of the central postulates of net neutrality, ${ }^{60}$ it is fair to say that the ECtHR in Cengiz $v$ Turkey and Ahmet Yildirim $v$ Turkey has-at least marginally-touched aspects of this principle in the realm of an interpretation of Article 10 ECHR. Beyond the mentioned case law of the ECtHR, Recommendation CM/Rec(2016)1 of the Council of Europe's Committee of Ministers on net neutrality ${ }^{61}$ may

\footnotetext{
${ }^{55}$ Ahmet Yıldırım v Turkey (application no 3111/10, ECtHR 2012), para 54.

56 Ibid, para 50, with reference to Autronic AG v Switzerland, 22 May 1990, series A no 178, para 47.

${ }^{57}$ Cengiz and Others $v$ Turkey (applications nos 48226/10 and 14027/11, ECtHR 2015).

58 Yıldirım v Turkey (n 55).

${ }^{59}$ Cengiz v Turkey (n 57) paras 62 and 74.

${ }^{60}$ Barbara van Schewick, Internet Architecture and Innovation (MIT Press, 2010) 220.

${ }^{61}$ Recommendation $\mathrm{CM} / \operatorname{Rec}(2016) 1$ of the Committee of Ministers to member States on protecting and promoting the right to freedom of expression and the right to private life with regard to network
} 
provide guidance for future interpretation of Article $10 \mathrm{ECHR}$ in cases involving the management of data flows on the Internet. ${ }^{62}$ The main target of Recommendation $\mathrm{CM} / \operatorname{Rec}(2016) 1$ is interferences with Internet traffic that 'result in blocking, discrimination or prioritisation of specific types of content, applications or services' ${ }^{63}$ For the Committee, such practices raise concerns regarding Article $10 \mathrm{ECHR}$ as well as the right to private life and the protection of personal data as covered by Article 8 ECHR and the Convention for the Protection of Individuals with regard to Automatic Processing of Personal Data (ETS No 108). ${ }^{64}$ The Recommendation rightly emphasises that the link between freedom of expression and the protection of private life and personal data is crucial in any discussion about how the normative contours of net neutrality are to be defined. Evidently, individuals need a private sphere to be protected in their communication as this is a precondition for autonomous opinion-building and subsequently participation in any discursive process. ${ }^{65}$

The above-cited case law of the ECtHR and the Recommendation of the Committee of Ministers provide evidence that net neutrality is conceived broadly by the Strasbourg authorities as an important social value interrelating with several Convention rights, including freedom of expression and information, the right to private life, and the protection of personal data. What we have before us, so far, are mainly a number of crystallisation points of an emerging norm, but we are still far away from being able to identify tangible contours of a new right protecting the open Internet. One of the questions that remains unanswered is what the scope of protection of such a right would be. In my view the new right should not only protect individuals in their communication online but, beyond that, should also protect the objective preconditions of individual communication. Hence, we would need a right that would also protect the Internet as an institution.

If we widen the focus of our search for normative evidence indicating an institutional protection of the Internet, we find interesting case law of the German Constitutional Court. In a 2008 landmark decision, the German Constitutional Court acknowledged that people using the Internet as a means for communication should be protected in their expectations of the

neutrality, adopted by the Committee of Ministers on 13 January 2016, at the 1244th meeting of the Ministers' Deputies.

${ }^{62}$ As a matter of fact the ECtHR often refers to Recommendations of the Committee of Ministers when interpreting the ECHR.

${ }^{63}$ Recommendation CM/Rec(2016)1, (n 61) para 2.

64 lbid, para 3.

${ }^{65}$ UN Human Rights Council (HRC), 'Report of the Special Rapporteur on the Promotion and Protection of the Right to Freedom of Opinion and Expression, Frank La Rue', 17th Session (UN Doc A/HRC/17/27, 2011), para 53; Council of the European Union, 'EU Human Rights Guidelines on Freedom of Expression Online and Offline', Foreign Affairs Council Meeting (12 May 2014), 18. See also Julie E Cohen, Configuring the Networked Self: Law, Code and the Play of Everyday Practice (Yale University Press, 2012) 110-15. 
integrity of the technology they are using. ${ }^{66}$ The case dealt with remote computer searches by government authorities, and as a result, the Court adopted an unwritten basic right of the German Constitution (Grundgesetz) 'to the guarantee of the confidentiality and integrity of information technology systems ${ }^{\prime}{ }^{67}$ The Court held that the government was not allowed to use spy or surveillance software to infiltrate information technology systems because of the newly adopted right of the Grundgesetz, unless there were exceptional circumstances. Infiltration is to be understood as secret intrusion into an information system that makes it possible to monitor the use of the target system, view stored media and control the target system remotely, ie spying on a system as a whole. ${ }^{68}$ The 'integrity' of the system is threatened by the ability of the infiltrators to delete, alter or create new data. ${ }^{69}$ What 'information technology system' means exactly was not defined by the Court. However, it stated that the Internet 'consists of information technology systems, and can itself also be regarded as an information technology system'. ${ }^{70}$ In other words, the Court established a right to 'network integrity' as far as necessary for the newly adopted right. The Court also made it clear that it had to be a system the access to which would allow one to obtain detailed insight into the personality of the person concerned. ${ }^{71}$ Although the new right was developed out of the right of personality (Art 2.1 in conjunction with Art 1.1 of the Grundgesetz), it has been argued in the academic literature that the relevance of the integrity of information technology systems goes beyond the protection of individual autonomies, ${ }^{72}$ reaching out to institutional (objective) aspects of communicative freedom online. The German Constitutional Court's ruling was revolutionary, but it is limited in scope due to being restricted to state actions. ${ }^{73}$ There is, though, an obvious similarity between the measures or software that the Court was trying to protect against and the technologies that private companies use to monitor Internet users' online behaviour. As we know, some of these private actors are more powerful than many states.

${ }^{66}$ BVerfG, 1 BvR 370/07, 27 February 2008; an English translation is available online: <www.bverfg.de/ entscheidungen/rs20080227_1bvr037007en.html>.

${ }^{67} \mathrm{lbid}$, paras 100 and 135.

${ }_{68}^{68} \mathrm{lbid}$, paras 5 and 122.

${ }^{69}$ Ibid, para 174.

70 lbid, para 4.

${ }^{71}$ Ibid, para 137.

72 Vagias Karavas, 'Das Computer-Grundrecht: Persönlichkeitsschutz unter informationstechnischen Bedingungen' (2010) 7(2) WestEnd: neue Zeitschrift für Sozialforschung 95.

${ }^{73}$ The fact that fundamental rights apply only in relations between an individual and the state is still a general problem of fundamental rights doctrine. The ECtHR, for example, generally requires interference by a public authority in the exercising of the rights guaranteed by the ECHR as a precondition for a decision on the merits of a case. See eg Cengiz $v$ Turkey ( $n$ 57) para 57. For a comparative discussion of this problem in a cyberspace context see Christoph B Graber, 'Internet Creativity, Communicative Freedom and a Constitutional Rights Theory Response to "Code is Law"'in Sean Pager and Adam Candeup (eds), Transnational Culture in the Internet Age (Edward Elgar, 2012) 135-64, 153-7. 
Secret surveillance of Internet communication is likely to produce chilling effects on free speech, as empirical research has demonstrated. ${ }^{74}$ Hence, the expectation of an undisturbed and non-manipulated functioning of the technological medium is required for the enjoyment of individual and social communicative autonomy on the Internet. Interference with the Internet's functionality that is not transparent would be particularly harmful in this respect. Since confidence in the integrity of Internet communication is a precondition for communicative freedom, the normative purpose of a new fundamental right of the Internet should include, inter alia, a guarantee for everyone to a process of communication that is free from any kind of manipulation of its technical functionality. ${ }^{75}$ Such protection should be effective not only against governments but also against private actors.

\section{The constitutionalisation of net neutrality}

\subsection{Empirical evidence from the United States}

Timothy Wu introduced network neutrality in a 2003 paper as a novel 'non-discrimination principle' providing that 'absent evidence of harm to the local network or the interests of other users, broadband carriers should not discriminate in how they treat traffic on their broadband network on the basis of internetwork criteria. ${ }^{76}$ What $\mathrm{Wu}$ had in mind was a principle that would be able to strike a balance between the 'inter network', where broadband operators must abstain from restrictions, and the local network, where they should be allowed 'to police what they own'. ${ }^{77}$ Despite its admitted 'vagueness ${ }^{78}$ and lack of a legal foundation, the principle took off meteorically and it rapidly became a key benchmark in political debates about the future of the Internet's architecture. The FCC referred to the principle's guiding theme for the first time ${ }^{79}$ in a 2005 Statement on Internet policy, ${ }^{80}$ determining that 'the Commission has jurisdiction necessary to ensure that providers of telecommunications for

\footnotetext{
74 Jonathan W Penney, 'Chilling Effects: Online Surveillance and Wikipedia Use' (2016) 31(1) Berkeley Technology Law Journal 1.

${ }^{75}$ See Vagias Karavas, Digitale Grundrechte: Elemente einer Verfassung des Informationsflusses im Internet (Nomos, 2007) 196.

${ }^{76} \mathrm{Wu}(\mathrm{n} \mathrm{3)} 171$.

77 lbid, 168.

${ }^{78}$ Ibid.

${ }^{79}$ Around the same time, network neutrality was also an issue in the 2005 Madison River Case. In that case, the FCC Bureau initiated an inquiry about 'allegations that Madison River was blocking ports used for VolP applications, thereby affecting customers' ability to use VolP through one or more VolP service providers'. The case was ultimately settled out of court. In the consent decree that was referenced in an FCC order, Madison River agreed not to 'block ports used for VolP applications or otherwise prevent customers from using VolP applications'. Although 'network neutrality' was at issue, the name of the concept was not mentioned. See Federal Communications Commission, Madison River Communications, LLC and affiliated companies, Order, File No EB-05-IH-0110, DA 05-543, adopted 3 March 2005.

${ }^{80}$ A preliminary step leading to the 2005 Internet Policy Statement was a February 2004 speech of FCC's Chairman Powell discussing a set of network principles. See Michael Powell, 'Preserving Internet
} 
Internet access or Internet Protocol-enabled (IP-enabled) services are operated in a neutral manner'. ${ }^{81}$ The policy statement provided for a number of network neutrality principles concerning the encouragement of 'broadband deployment' and the preservation and promotion of the 'open and interconnected nature of the public Internet'. Based on these principles, the FCC, in a 2008 order, prohibited Comcast from throttling Bittorrent traffic when providing broadband Internet access over its cable lines. ${ }^{82}$ This was the FCC's first attempt to turn network neutrality into a legal concept. It was not successful as the Court of Appeals for the DC Circuit reversed the FCC order on 6 April 2010, determining that there was no legal basis in the Communications Act that would authorise the FCC to regulate Comcast's network management practices. ${ }^{83}$ The court recalled the FCC's still-binding 2002 Cable Modem Order, where 'the Commission [had] ruled that cable Internet service is neither a "telecommunications service" covered by Title II of the Communications Act nor a "cable service" covered by Title VI'. ${ }^{84}$ In response to the court ruling, the FCC adopted the so-called Open Internet Order on 21 December $2010 .^{85}$ The Commission reasoned that the newly adopted protections 'are grounded in broadly accepted Internet norms' ${ }^{86}$ Obviously, the Court of Appeals did not share this view since on 14 January 2014 it struck down the FCC order in Verizon v FCC, again due to its insufficient legal foundation. ${ }^{87}$ More precisely, the court brushed off the FCC's authority to enforce rules on network neutrality on the grounds that ISPs are not identified as common carriers. ${ }^{88}$ The same day,

Freedom: Guiding Principles for the Industry', online: <https://transition.fcc.gov/commissioners/ previous/powell/speeches.html>.

${ }^{81}$ Federal Communications Commission, Broadband Access to the Internet, Policy Statement, GN Docket No 00-185, CS Docket No 02-52, FCC 05-151, adopted 5 August 2005, p 3.

82 Federal Communications Commission, 'Formal Complaint of Free Press and Public Knowledge Against Comcast Corporation for Secretly Degrading Peer-to-Peer Applications, Memorandum Opinion and Order', File No EB-08-IH-1518, WC Docket No 07-52, FCC 08-183, adopted 1 August 2008. See also Hart (n 2) 433-4.

${ }^{83}$ Comcast v FCC (n 4) 3.

84 lbid, 5.

${ }^{85}$ Federal Communications Commission (n 5).

${ }^{86}$ Federal Communications Commission, Preserving the Open Internet, Federal Register, Vol 76, No 185, 23 September 2011, 59192-59235. 'The Commission adopts three basic protections that are grounded in broadly accepted Internet norms, as well as our own prior decisions. First, transparency: fixed and mobile broadband providers must disclose the network management practices, performance characteristics and commercial terms of their broadband services. Second, no blocking: fixed broadband providers may not block lawful content, applications, services or non-harmful devices; mobile broadband providers may not block lawful Web sites, or block applications that compete with their voice or video telephony services. Third, no unreasonable discrimination: fixed broadband providers may not unreasonably discriminate in transmitting lawful network traffic' (59192).

${ }^{87}$ Verizon v FCC (n 7).

${ }^{88}$ Robertson (n 8). Considering ISPs as 'common carriers' would have required defining broadband services as 'telecommunication services' (covered by Title II of the Telecommunications Act) rather than 'information services' (covered by Title I of the Telecommunications Act). In a number of decisions between 2001 and 2005 the FCC had classified broadband services as 'information services'. These decisions were upheld by the US Supreme Court in NCTA v Brand X, 545 U.S. 967 (2005) as permissible though not required. See Robert Faris et al 'Score Another One for the Internet?: The Role of the Networked Public Sphere in the U.S. Net Neutrality Policy Debate', Berkman Center for Internet and Society 
Timothy $\mathrm{Wu}$ commented on the verdict in a newspaper interview, criticising the FCC for opting for the wrong strategy when 'arguing that its rules are not common carrier rules' in the sense of Title II of the US Communications Act. ${ }^{89} \mathrm{Wu}$ recommended that the FCC should now 'reclassify broadband under Title II authority'. He agreed with the interviewer's remark that such a radical decision would be likely to cause a lot of political resistance, but insisted that it was now time 'to get people in Congress excited about that'. 90

The job of getting 'people in Congress excited' about net neutrality has since been taken seriously by a number of Internet advocacy and public interest groups engaging in a unique lobbying campaign for the cause of a free and open Internet infrastructure. Notably, the FCC now also understood the importance of civil society feedback and invited people to comment on its new proposal for open Internet rules, published as 'Notice of Proposed Rulemaking' on 15 May 2014. ${ }^{91}$ One of the most active participants in this process was Public Knowledge, a Washington DC based public interest group. Public Knowledge filed detailed comments with the FCC on 15 July 2014, the first day of the consultation procedure, primarily criticising the FCC's distinction between fast lanes and slow lanes online. ${ }^{92}$ Public Knowledge, Electronic Frontier Foundation (EFF), BattlefortheNet and other influential Internet advocates ${ }^{93}$ mobilised hundreds of thousands of supporters to directly send comments to the FCC expressing how they would view a truly open Internet architecture. Their mobilisation campaign was so successful that the FCC's website broke down due to a massive surge in traffic ${ }^{94}$ and the Commission was forced to extend the timeframe for filing comments. ${ }^{95}$

at Harvard University, February 2015, 11-12, online: <https://cyber.law.harvard.edu/sites/cyber.law. harvard.edu/files/2015_02_10_Score_Another_One_for_the_Internet_0.pdf $>$.

${ }^{89}$ Brian Fung, "'A FEMA-level fail": The law professor who coined "net neutrality" lashes out at the FCC's legal strategy', The Washington Post (14 January 2014), online: <www.washingtonpost.com/news/theswitch/wp/2014/01/14/a-fema-level-fail-the-law-professor-who-coined-net-neutrality-lashes-out-at-

90 lbid.

${ }^{91}$ Federal Communications Commission, Protecting and Promoting the Open Internet, Notice of Proposed Rulemaking, GN Docket No 14-28, FCC 14-61, adopted 15 May 2014. On p 64 the rules for filing comments were detailed, and two deadlines of 15 July and 10 September 2014 were set for filing comments and replying to comments, respectively.

92 Public Knowledge, Official Comments for FCC Net Neutrality Proceeding, 15 July 2014, online: <www. publicknowledge.org/documents/official-comments-for-fcc-net-neutrality-proceeding >.

93 John Oliver, host of the widely popular HBO weekly comedy news programme Last Week Tonight dedicated the show of 1 June 2014 to the topic of net neutrality. He heavily criticised the FCC's plan to allow fast lanes and implored his fans to send their comments to the FCC to save the free and open Internet. See $<$ www.youtube.com/watch? $v=$ fpbOEoRrHyU $>$. Oliver's show had a huge mobilising effect, as an analysis by the Berkman Klein Center confirms. See Faris et al (n 88) 17-18.

${ }^{94}$ Alex Wilhelm, 'After Users Swamp its Website, the FCC Extends the Net Neutrality Comment Period to Friday', Techcrunch (15 July 2014), online: <http://techcrunch.com/2014/07/15/after-users-swamp-itswebsite-the-fcc-extends-the-net-neutrality-comment-period-to-friday/>.

${ }^{95}$ Federal Communications Commission, 'Wireline Competition Bureau Extends Deadline for Filing Reply Comments in the Open Internet and Framework for Broadband Internet Service Proceedings', GN Docket Nos 14-28, 10-127, Public Notice, DA 14-1199. 
The more than 2 million comments made through the FCC's Electronic Comment Filing System can be publicly accessed online. ${ }^{96}$ Altogether, the FCC received more than 3.7 million comments at this initial stage. ${ }^{97} \mathrm{~A}$ detailed analysis of the filed comments was undertaken by the 'Sunlight Foundation', a Washington-based NGO advocating for open government. The analysis of the first round of comments (800,000 comments analysed) revealed, inter alia, that less than one per cent of the commenters rejected the principle of net neutrality, two thirds rejected the idea of fast lanes, and two thirds called on the FCC to reclassify ISPs as 'common carriers' ${ }^{98}$ The second round of comments was also analysed, revealing that 60 per cent of the analysed 1.6 million comments rejected net neutrality. The analysts explained this surprising result with the fact that most of the negative comments resulted from a campaign that was organised by 'American Commitment', a right-wing non-profit organisation. ${ }^{99}$ This organisation provided anti-net neutrality response-letter templates and successfully convinced its constituency to send them to the FCC. ${ }^{100}$ Of the commenters that did not use the letter template from 'American Commitment', only one per cent rejected network neutrality. ${ }^{101}$ When the FCC passed the strong net neutrality rules on 26 February 2015, Internet advocacy groups such as Public Knowledge $^{102}$ and $\mathrm{EFF}^{103}$ saw this as a victory for online democracy, a victory for the millions who had commented with the FCC, called Congress, and written to the White House. This view was confirmed by the FCC's press release, mentioning that it was 'the nearly 4 million commenters who participated in the FCC's Open Internet proceeding' who convinced the FCC to

${ }^{96}$ FCC Electronic Comment Filing System, see <http://apps.fcc.gov/ecfs/comment_search_solr/doSearch? proceeding $=14-28>$.

97 Alex Wilhelm, 'The FCC Received 3.7 Million Net Neutrality Comments', Techcrunch (16 September 2014), online: <http://techcrunch.com/2014/09/16/the-fcc-received-3-7-million-net-neutralitycomments/> (the figure was later officially adjusted to 'nearly 4 million', see Federal Communications Commission (n 1)).

${ }^{98}$ Bob Lannon and Andrew Pendleton, 'What can we learn from 800,000 public comments on the FCC's net neutrality plan?' Sunlight Foundation (2 September 2014), online: <http://sunlightfoundation.com/ blog/2014/09/02/what-can-we-learn-from-800000-public-comments-on-the-fccs-net-neutrality-plan/>.

${ }^{99}$ Andrew Pendleton and Bob Lannon, 'One group dominates the second round of net neutrality comments', Sunlight Foundation (16 December 2014), online: <http://sunlightfoundation.com/blog/2014/ 12/16/one-group-dominates-the-second-round-of-net-neutrality-comments/>.

${ }^{100}$ According to the Sunlight Foundation, 'Comments from this campaign had a shared template, with different targeted messages inserted between the second and third paragraph. Those targeted messages centered on topics as far ranging as personal freedoms, economic threats, the poor state of US public utilities, and the characterization of pro-NN advocates as extreme leftists'. The campaign led by American Commitment was single-handedly responsible for 56.5 per cent of the comments in this round. See Pendleton and Lannon (n 99).

101 Pendleton and Lannon (n 99).

102 Michael Weinberg, 'Landmark Day for Net Neutrality', Public Knowledge (15 September 2014), online: $<$ www.publicknowledge.org/news-blog/blogs/a-landmark-day-for-net-neutrality>.

103 Jeremy Gillula and Mitch Stoltz, 'Dear FCC: Thanks for Listening to Team Internet!', Electronic Frontier Foundation (26 February 2015), online: <www.eff.org/deeplinks/2015/02/fcc-votes-net-neutrality-bigwin>. 
adopt new rules on net neutrality that 'are guided by three principles: America's broadband networks must be fast, fair and open'. ${ }^{104}$

The FCC Report and Order of 26 February 2015 relies on authority derived from the FCC's reclassification of broadband Internet access as a common carrier service under Title II of the US Communications Act. The reclassification together with Section 706 of the Telecommunications Act of 1996 provides the legal foundation of the new rules. Hence, the FCC positively responded to the many comments that had recommended reclassifying broadband Internet service suppliers as 'common carriers'.

Reading the 2015 FCC Order, it is striking to see that throughout most of the report's 400 pages the FCC continually refers to opinions and views received from the commenters. Notably, at para 114 of the Order, the FCC mentions that it had abandoned the originally proposed idea of fast lanes, due to arguments put forward in many of the received comments. ${ }^{105}$ The Commission's explicit references to comments received demonstrates that the FCC developed and legally formalised its position on open Internet rules based not on expert views but on a public discourse that encompassed a variety of voices, including those of broadband providers, public interest groups and other civil society stakeholders.

The FCC's decision triggered a new attack by the cable, telecom and wireless Internet providers in the legal battle over net neutrality. This time, however, the Court of Appeals for the DC Circuit upheld the FCC rules in a two-to-one decision of 14 June $2016 .{ }^{106}$ The Court rejected the petitioner's numerous challenges to the Commission's reclassification of the broadband service as a telecommunications service. Thus, the Court ruled that the FCC's 2015 Open Internet Order had a legal foundation and that the promulgated net neutrality rules are valid. Although the Court of Appeal's decision was groundbreaking, the juridification of net neutrality remains contingent as the losing parties immediately announced they would bring the case before the US Supreme Court. ${ }^{107}$

\footnotetext{
${ }^{104}$ See Federal Communications Commission, 'FCC adopts Strong, Sustainable Rules to Protect the Open Internet', FCC Press Release (26 February 2016) 1, online: <http://transition.fcc.gov/Daily_Releases/ Daily_Business/2015/db0226/DOC-332260A1.pdf>.

105 Federal Communications Commission (n 1): 'After consideration of the record, we reject the minimum level of access standard. Broadband providers, edge providers, public interest organizations, and other parties note the practical and technical difficulties associated with setting any such minimum level of access. For example, some parties note the uncertainty created by an indefinite standard. Other parties observe that in creating any such standard of service for no-blocking, the Commission risks jeopardizing innovation. We agree with these arguments and many others in the record expressing concern with the proposed minimum level of access standard' (para 114).

106 United States Telecom Association v FCC (14 June 2016) USCA 15-1063 (DC Circuit).

107 See Cecilia Kang, 'Court Backs Rules Treating Internet as Utility, Not Luxury', New York Times (14 June 2016), online: <www.nytimes.com/2016/06/15/technology/net-neutrality-fcc-appeals-court-ruling. html?_r=0>.
} 


\subsection{Theoretical classification}

The empirical evidence from the United States shows that net neutrality is a young and nascent concept. As a rather vague idea originally aired in academic circles, it was taken up by civil society exponents once the contours of an (initially) latent conflict between private and public interests in the design of the Internet architecture became more clearly visible. An early incident triggering the concern of Internet advocates was the Madison River Case in 2005. ${ }^{108}$ In this case Madison River, a telephone company, blocked Voice over IP applications of Vonage, one of its access customers, in order to exclusively control Internet telephony services. ${ }^{109}$ This case was settled out of court and the word 'neutrality', although clearly at issue, was not mentioned in the Consent Decree that was referenced in the FCC Order of 3 March $2005 .{ }^{110}$ The Madison River case got Public Knowledge to publish a White Paper in 2006, also reporting on a number of other cases where ISPs had been blocking or discriminating Internet traffic. ${ }^{111}$ The White Paper explicitly warned against the risks for the open Internet architecture caused by ISPs increasingly introducing distinctions between fast and slow lanes online in order to extract higher profits from price differentiation. Public Knowledge, in conclusion, announced it would join other civil society initiatives in their efforts to call upon 'Congress to enact, or the FCC to adopt, an enforceable "Net Neutrality" rule to ensure the Internet remains open and accessible to all'. ${ }^{112}$ The wording of this announcement showed that the project was still broadly formulated at this stage and that a clear view of the declared target and a detailed strategy of how to get there were still missing. In the Comcast case, then, the company's discrimination between types of content as a technological weapon against copyright piracy stirred up a hornets' nest. Due to the huge popularity of file sharing among the youth, this provoked an enormous outcry and helped net neutrality rapidly gain prominence within larger segments of society. ${ }^{113}$ The FCC's 2008 order prohibiting Comcast from throttling P2P content and requiring it to respect 'net neutrality' was the Commission's first Internet management decision, implementing the open Internet principles set forth in its 2005 Statement of Internet Policy in a pilot case. ${ }^{114}$ The wrangling between the FCC and telecom lobbies that followed in the

\footnotetext{
${ }^{108}$ For the reference, see $\mathrm{n} 79$.

109 Hart (n 2) 422; Simon Schlauri, Network Neutrality: Netzneutralität als neues Regulierungsprinzip des Telekommunikationsrechts (Nomos, 2010) 156-7.

110 See Federal Communications Commission (n 79).

111 John Windhausen Jr, 'Good Fences Make Bad Broadband: Preserving an Open Internet through Net Neutrality', Public Knowledge White Paper (6 February 2006) 16-23, online: <www.publicknowledge. org/pdf/pk-net-neutrality-whitep-20060206.pdf>.

112 Ibid, 2.

${ }^{113}$ Comcast was accused of having secretly throttled data from customers using Bittorrent, a file-sharing software. See Sonia Katyal, 'Filtering, Piracy Surveillance and Disobedience' (2009) 32(4) Columbia Journal of Law and the Arts 401, 417-18.

${ }^{114}$ Federal Communications Commission (n 81).
} 
years after the Comcast decision helped issues of net neutrality to climb up the agenda of national politics. The 2015 decision of the FCC can be seen as a further milestone in the process of the institutionalisation of net neutrality as a social value. This is a quite extraordinary story. Within a short space of time, net neutrality gradually evolved from being an idealistic 'dream' exclusively discussed in highly specialised academic circles, to becoming a 'battle cry' capable of mobilising millions of people for collective action. In a recent analysis, the Berkman Klein Center compared the net neutrality debate with the battle against the Stop Online Piracy Act (SOPA) and the Protect Intellectual Property Act (PIPA) in 2011-2012, which was a prior example of massive social mobilisation over the Internet. Whereas the SOPA/PIPA debate was merely defensive, as its purpose was to prevent stricter legislation on copyright enforcement, the debate about net neutrality is the first major example of a successful campaign to achieve an affirmative rule change in the teeth of well-organized lobbying opposition. ${ }^{115}$

The Berkman Klein Center analysed the last 12 months before the 2015 decision of the FCC, focusing on the impact of the networked public sphere on collective action. It found that the strongly approving networked public sphere mobilised millions of people to send comments and emails to the regulatory and political authorities. Eventually, this persuaded the FCC to alter its stance regarding the classification of broadband services and to do what was necessary to effectively protect net neutrality. ${ }^{116}$ Strikingly, the dynamics leading to the institutionalisation of net neutrality did not originate from the brains of a few political leaders but sprang up from the bottom levels of society. ${ }^{117}$ According to the Berkman Klein Center, the mainstream media as well as Internet-based social networking services were used by a variety of proponents of net neutrality as vehicles for social mobilisation. ${ }^{118}$ The fact that it was possible to mobilise such a large number of Internet users within a short period of time is extraordinary. Certainly, the means of information technology in general and social networks in particular have facilitated active participation of citizens. ${ }^{119}$ At the same time they have also manifested dangers as with the dissemination of response-letter templates through

\footnotetext{
115 Faris et al (n 88). For a quantitative and qualitative analysis of the mobilisation in the SOPA-PIPA campaign see Yochai Benkler et al 'Social Mobilisation and the Networked Public Sphere: Mapping the SOPA-PIPA Debate' (Berkman Klein Center Research Publication No 2013-16 (2013)) online: <www. ssrn.com/abstract $=2295953>$.

116 The Berkman Klein Center's study confirms that the dynamics of the networked public sphere were instrumental in turning around the FCC's policy on net neutrality and scoring 'one of the more unlikely political victories Americans have seen in a long time'. Faris et al (n 88) 21.

117 The fact that President Obama spoke out in favour of strong net neutrality rules on 10 November 2014 does not contradict this analysis. See Faris et al (n 88) 22. Although Obama's intervention was important for the FCC, it came rather late in the process, at a time when the networked public sphere was already strongly favouring net neutrality.

${ }^{118}$ Faris et al (n 88) 23.

119 Ibid, 32.
} 
'American Commitment'. ${ }^{120}$ On balance, the fact that millions of people not only stood up for an open and neutral Internet but also took the trouble to write letters and emails and to send comments to the regulator and political authorities is evidence of a robust institutionalisation of net neutrality as a high-ranking social value in the United States. ${ }^{121}$

In the sense of Gunther Teubner's theorising, we are in the midst of a process of societal constitutionalism. Teubner understands the development of civil constitutions as a process over three steps, starting with the emergence of normative expectations from a specific sub-system in a reflexive process, followed by juridification, and in the third step, a second reflexive process where constitutional structures emerge. ${ }^{122}$

With regard to the first step, it first needs to be clarified what the specific sub-system would be in the case of constitutionalism in cyberspace. Teubner's answer would probably be the Internet, as he considers the Internet to be an autonomous social system. ${ }^{123}$ I would not find such a solution to be theoretically and empirically compelling. The Internet is quite different from all the well-known social systems that have been analysed in the seminal literature of sociological systems theory. Luhmann distinguishes four general types of systems including psychic systems, social systems, organisms and machines. ${ }^{124}$ The particularity of social and psychic systems is meaning ${ }^{125}$-these systems are in the business of producing meaning. Thus, meaning allows one to differentiate between psychic and social systems on the one hand and organisms and machines on the other hand. However, meaning does not allow one to distinguish between social systems and

\footnotetext{
120 In a 2007 exploratory survey of 1,556 citizen participants in regulatory public comment processes in the US, Schlosberg et al found considerable differences between commenters who submit original comments and commenters who submit a form comment. The latter group appeared to be generally less educated, less informed about politics and more negative about the government. David Schlosberg et al, 'Democracy and E-Rulemaking: Web-Based Technologies, Participation, and the Potential for Deliberation' (2007) 4(1) Journal of Information Technology \& Politics 37, 48-49. A recent representative study sheds critical light on the reliability of public consultations on net neutrality with selfselected respondents. See René CG Arnold et al, 'All But Neutral: Citizen Responses to the European Commission's Public Consultation on Network Neutrality' in Luca Belli and Primavera de Filippi (eds), Net Neutrality Compendium, Human Rights, Free Competition and the Future of the Internet (Springer International Publishing, 2016) 199. Two findings of the study are noteworthy. First, the study found indications 'of a strong underlying self-selection bias' in public consultations on net neutrality ( $p 205)$. Second, the study revealed that it is difficult for consumers to understand the terminology and the concept of net neutrality without further explanations ( $p$ 203). Hence, one may conclude from this study that any survey on net neutrality is susceptible to influence from or manipulation by its designer.

121 This conclusion is not invalidated by the fact that overall only a minority of the US population have ever heard of net neutrality or know what the concept stands for. See Center for Political Communication, 'National Survey on Net Neutrality', University of Delaware (10 November 2014), online: <www.udel. edu/cpc/research/fall2014/UD-CPC-NatAgenda2014PR_2014NetNeutrality.pdf>.

122 Teubner, Constitutional Fragments (n 33).

${ }^{123}$ Teubner, 'Societal Constitutionalism' (n 33) 21.

${ }^{124}$ Niklas Luhmann, Social Systems, translated by John Bednarz with Dirk Baecker (Stanford University Press, 1995) 2.

$125 \mathrm{Ibid}, 59-102$.
} 
psychic systems. Luhmann therefore needed elements that were particular to social systems. He did not choose actions of human beings as other social theorists (eg Jürgen Habermas) have. Luhmann chose communications as the basic elements of social systems. ${ }^{126}$ Hence, social systems are communicative systems. With their communications social systems produce meaning, as is the case with the law, politics, the economy, science, mass media, art, religion, education, family and love-the most prominent social systems that have been analysed by Luhmann. By contrast, the Internet is more a machine than a communicative system. It belongs to the material world since it consists of a network of interconnected computers. As a network, the Internet is morphologically hybrid. Although the Internet does not directly produce meaning, by the networking of computers it materially designs the linking up of communicative events. ${ }^{127}$

According to Luhmann, communications are produced by social systems as events, which occupy a minimal time span before they disappear. Luhmann emphasises that

[a]ll structures of social systems have to be based on this fundamental fact of vanishing events, disappearing gestures or words that are dying away. Memory, and then writing, have their function in preserving not the events, but their structure-generating power. ${ }^{128}$

Similarly, the Internet's function is to preserve the structure-generating power of communicative events. It does so by networking an unlimited number of computers which are used as the technical means for communication. Therefore, the Internet cannot itself be an event. An event produced by one system may also irritate the autopoiesis of a second system that is observing the first system. By these means a structural coupling of social systems is established. ${ }^{129}$ A structural coupling is defined by Luhmann as a co-evolution of two systems that is triggered by a certain communicative event which is in the environment of both systems. ${ }^{130}$ Systems may observe a communicative event in their environment as an irritant, and such irritation may trigger structural adaptations within the system, according to the evolutionary processes of variation, selection and stabilisation. If such an event is of longer duration it becomes an episode. A constitution of a nation state is an example of an episode coupling the legal system and the political system. Hence, there is a trans-discursive relationship between the material elements of the network (computers, algorithms, electronic signals, wires, etc) and the

\footnotetext{
${ }^{126}$ Niklas Luhmann, 'The Autopoiesis of Social Systems' in RF Geyer and J van der Zouwen (eds), Sociocybernetic Paradoxes: Observation, Control, and Evolution of Self-Steering Systems (Sage Publications, 1986) 172-92, 174-6.

${ }^{127}$ For a similar view see Dan Wielsch, Zugangsregeln (Mohr Siebeck, 2008) 236-8.

128 Luhmann (n 126) 180.

129 See Luhmann (n 30) 381-422.

130 lbid.
} 
discursive sphere of the (structurally coupled) social systems, which, for their part, are structurally coupled through communicative events. In the case of net neutrality, such events may trigger a structural coupling between various function systems, including between the economic system and the law or between the economic system and the political system, for example. Which structural coupling can be observed is a question of the observer's perspective.

If not the Internet, what else? Of all the systems involved in the communication about net neutrality, I consider the economic system to be the one of greatest relevance for the emergence of normative expectations. The debate about net neutrality is very much about money, as demonstrated, for example, by the dispute over the creation of fast lanes. ${ }^{131}$ It is in the economic system where we witness the emergence of normative expectations that are related to preserving an open and neutral Internet.

We can describe this as reflexive interaction between the organised professional sphere and the spontaneous sphere of the system, a distinction suggested by Teubner's theory of societal constitutionalism. ${ }^{132}$ In the organised sphere of the Internet economy we find the major cable and telephone companies, including Madison River, Comcast, Verizon, AT\&T and others. As mentioned, these companies have been among the main protagonists in the leading court cases on net neutrality where they have defended their economic interests, and more particularly their ability to conduct network management practices. It is therefore no surprise that the major US telecom firms also filed a Petition for Review against the FCC's Title II Order of February $2015 .{ }^{133}$ The main interest of the telecom lobby was to prevent a limitation of their economic power that would be caused by enforceable rights of net neutrality. ${ }^{134}$ In the spontaneous sphere of the system we find the Internet advocacy groups, civil rights movements, consumer organisations, public interest groups, etc that have been active in social media networks and other fora taking part in the debates about strengthening the values of communicative freedom and open Internet. These interventions have chiefly been aimed at introducing limitative elements into the constitution of the Internet

131 The creation of fast lanes would have allowed ISPs to offer higher-speed services for content providers willing to pay extra for privileged Internet access. Critics argued that this 'would raise prices for customers of streaming video services' and disadvantage start-ups and not-for-profit Internet organisations who would not have the financial means to pay higher prices. See Center for Political Communication, 'National Survey on Net Neutrality', University of Delaware (10 November 2014), online: <www.udel.edu/cpc/research/fall2014/UD-CPC-NatAgenda2014PR_2014NetNeutrality.pdf>. See also Inimai M Chettiar and J Scott Holladay, 'Free to Invest: The Economic Benefits of Preserving Net Neutrality', Institute for Policy Integrity at New York University School of Law (January 2010) 39-47, online: <http://policyintegrity.org/documents/Free_to_Invest.pdf >.

132 Teubner, Constitutional Fragments, (n 33) 88-102.

133 See Michael Powell, 'Why we are appealing the FCC's title II decision', National Cable \& Telecommunications Association (NCTA) (14 April 2015), online: <www.ncta.com/platform/public-policy/why-we-areappealing-the-fccs-title-ii-decision>.

134 Hart (n 2) 425-7. 
economy. The process is reflexive because in the competing relationship between the spontaneous and the formally organised spheres, net neutrality matured from being a vague idea to eventually becoming a concept with more precise normative contours. The interplay between the two spheres has proved to be difficult since the organised sphere generally does not receive direct input from the spontaneous sphere. Indirect influences would be possible, for example, through consumers of telecommunication or Internet access services making their consumption decisions conditional on telecom companies voluntarily refraining from discriminating certain traffic on their networks.

In a second step, according to Teubner, constitutionalisation would require a juridification of the self-founded normative expectations. ${ }^{135}$ In the language of systems theory this should be understood as a structural coupling between the economic system and the legal system. As a direct flow of information from one system to the other is not possible, structural coupling is the only possibility for a resonance between systems. Accordingly, the above identified reflexive mechanisms of the economic system are coupled with the reflexive mechanisms of the law, which consist of 'secondary legal norm creation in which norms are applied to norms. ${ }^{136}$ The structural coupling led to the FCC's Title II Order of February 2015. In a communication process primarily with the Court of Appeals of the DC Circuit, the telecom lobby and civil society, the FCC was able to sharpen the normative contours of net neutrality and eventually adopt rules that were clear, rigorous and enforceable. Certainly, the juridification process has not yet come to an end as the losing telecom companies announced they would be bringing the matter before the US Supreme Court, after the Court of Appeals' decision of 14 June $2016 .{ }^{137}$ Moreover, it remains completely open whether net neutrality will survive the presidency of Donald Trump. Although Trump's position in this regard is still hard to predict at press time, several members of his FCC transition team have explicitly criticised net neutrality. ${ }^{138}$

To conclude, the social institutionalisation of net neutrality as a constitutional right appears to have reached an advanced level already. The concept's legal institutionalisation, however, is still in progress. That is not all. Before we would be able to speak of an institutionalisation of net neutrality as a fundamental right of the US Constitution, a second reflexive process within the legal system would need to take place. This third step in Teubner's theory is about the development of constitutional structures. At this stage, the

\footnotetext{
135 Teubner, Constitutional Fragments (n 33) 105-10.

136 Ibid, 105.

${ }^{137}$ Kang (n 107) and accompanying text.

138 See Russell Brandom, 'Will Net Neutrality Survive Donald Trump?', The Verge (30 November 2016), online: <www.theverge.com/2016/11/30/13795030/net-neutrality-donald-trump-fcc-repeal-openinternet>.
} 
normative expectations juridified in the above-mentioned structural coupling would be reviewed in a second reflexive process within the legal system. Such second order observation would likely take place before a higher court that would subject legal rules to a test regarding the question of whether these norms complied with the established norms of the constitution. Here, one needs to distinguish two steps: a first step where a constitutional court would decide that rules on net neutrality were in conformity with the constitution, and a second step where the court would declare net neutrality to be a constitutional right. Only the second step would produce the constitutional quality of net neutrality, operating a constitutional/unconstitutional binary code. Teubner emphasises that this constitutional code emerges from the social sphere concerned (the economy in the case at issue) via juridification/structural coupling with the legal system. ${ }^{139}$ In the case of the United States, such constitutional structures would emerge either through casebased incremental developments in the practice of the US Supreme Court, moving towards an eventual recognition of a fully fledged freedom or, what is less likely, through a constitutional amendment requiring supermajority consensus of either Congress alone or jointly with the several states, depending on the mode of proposal or ratification. ${ }^{140}$ In any event, such a process would take a long time.

\section{The relationship between social and formal constitutional structures}

The debate about net neutrality in the United States is a showcase for the spontaneous emergence of constitutional norms from the bottom of society. In the realm of the Internet it provides evidence validating the theoretical thesis underpinning this paper that constitutional norms commonly emerge from society as social values before they are juridified as constitutional rights and become part of the law. The question that remains to be addressed is how the process of societal constitutionalism relates to democratically legitimised formal procedures of constitution-making. How should this dualism between formally organised rationality and informal spontaneity be qualified from a democracy perspective?

Obviously, the spontaneous processes of constitutionalisation do not meet the formal requirements of constitutional change as they have not been enacted by democratically legitimised institutions according to formally prescribed procedures. However, while social constitutions lack democratic legitimacy, they may still be accepted by smaller or larger segments of society. As Max Weber has forcefully argued, there may indeed be acceptance

\footnotetext{
139 Teubner, Constitutional Fragments (n 33) 110-13.

140 Tribe (n 43) 95.
} 
without democratic legitimation. ${ }^{141}$ Weber's presumption is that legal subjects generally obey commands that are accepted. ${ }^{142}$ While democratic procedures further the acceptance of a norm, acceptance and democratic legitimation must still be distinguished. ${ }^{143}$ Theoretically, situations may exist where the processes producing democratic legitimation are defective or do not sufficiently include certain values, having not yet received clear normative contours. In the yet scarcely mapped digital networked environment it may indeed be that a social value such as net neutrality-although of crucial importance to the public interest-is not sufficiently represented in legislative processes that are often dominated by powerful lobbies pushing for particular corporate interests. ${ }^{144}$ A prime example of this is the net neutrality debate in the EU which, in its initial stages, was criticised for inadequately reflecting the public interest. ${ }^{145}$ Indeed, the EU law to safeguard open Internet access, which was adopted on 25 November 2015 (commonly referred to as the Telecoms Single Market Regulation), draws up a loose interpretative framework of net neutrality that does not exclude fast lanes or zero rating ${ }^{146}$ and provides a loophole definition of allowable traffic management interference. ${ }^{147} \mathrm{Com}$ menters have criticised the new rules for being the result of a debate dominated by a 'corporate interests come first' type of reasoning. ${ }^{148}$ In a detailed analysis, Jan Gerlach compares the net neutrality debates in the United States and EU and identifies a number of differences relating to, inter alia, difficulties in framing net neutrality in an intelligible way, the organisation of the telecom authorities, regulatory structures and civil society participation. ${ }^{149}$ In

${ }^{141}$ Max Weber, Economy and Society: An Outline of Interpretive Sociology, Volume 1, translated by Günther Roth, (University of California Press, 1978) 212-16.

142 David Trubek, 'Max Weber on Law and the Rise of Capitalism' (1972) 3 Wisconsin Law Review 720, 732.

${ }^{143}$ Armin von Bogdandy et al, In Whose Name?: A Public Law Theory of International Adjudication (Oxford University Press, 2014) 155.

${ }^{144}$ For a rich collection of examples where big Internet corporations have preferred to enhance their businesses rather than being socially responsible or furthering the public good, see Rebecca MacKinnon, Consent of the Networked: The World-Wide Struggle for Internet Freedom (Basic Books, 2012) 11565.

${ }^{145}$ In the tripartite debate on net neutrality in the EU, the contributions of the Commission and the Council have been criticised for a destructive attitude at various points in the negotiation process and for largely ignoring several earlier resolutions of the Parliament in favour of strict rules on net neutrality. See Joe McNamee and Maryant Fernández, 'Net Neutrality: An Analysis of the European Union's Trialogue Compromise' in Luca Belli and Primavera De Filippi (eds), Net Neutrality Compendium: Human Rights, Free Competition and the Future of the Internet (Springer International Publishing, 2016) 183-91.

146 Simply put, zero rating is a commercial practice whereby an Internet access provider exempts certain data traffic from any caps in place for Internet access or extra charges if a cap is exceeded. See Jeremy Malcolm, Corynne McSherry and Kit Walsh, 'Zero Rating: What It Is and Why You Should Care', Electronic Frontier Foundation (18 February 2016), online: <www.eff.org/deeplinks/2016/02/zero-ratingwhat-it-is-why-you-should-care $>$.

147 Regulation (EU) 2015/2120 of the European Parliament and of the Council of 25 November setting out measures concerning open Internet access, OJ 2015 L 310/1.

148 See James Temperton and Matt Burgess, 'European Parliament Votes in Favour of "Two Speed" Internet', Wired (27 October 2015), online: www.wired.co.uk/news/archive/2015-10/27/net-neutralityeuropean-union-vote.

149 Jan Gerlach, The Informational Ecosystem of Net Neutrality: A Comparison of Regulatory Discourses in the U.S. and the E.U. (Dike, 2016) 240-64. 
our context, the disparities relating to the last-mentioned issue are of the greatest interest. Regarding civil society involvement in the United States, it is important to recall that the FCC not only invited people to comment on its 2014 'Notice of Proposed Rulemaking' but also listened to them. Ultimately, it even abandoned its originally proposed idea of fast lanes in response to the received comments. ${ }^{150}$ The European Commission, by contrast, considered the consultation process merely as a fact-finding exercise. ${ }^{151}$ Moreover, a lack of transparency during stages of the negotiations made it difficult for the general public to follow the debate. ${ }^{152}$ Overall, there was very limited participation of civil society in the so-called trialogue between the Commission, Council and Parliament up to the adoption of the Telecoms Single Market Regulation in Autumn 2015.

Rather surprisingly, however, the situation changed when it was the turn of the Body of European Regulators for Electronic Communications (BEREC) to draft guidelines for the implementation of the net neutrality rules in the adopted Regulation at member state level. Apparently, BEREC was inspired by the net neutrality debate in the United States as experts from civil society were included in the process of creating the guidelines and publishing draft guidelines for public consultation on the implementation of new net neutrality rules. ${ }^{153}$ BEREC received almost half a million responses, which is a historic high considering that they had never received more than 100 responses in their previous consultations. ${ }^{154}$ A crucial player in this process was Save the Internet, a broad coalition of civil society exponents and Internet activists, which created a web page providing legal analysis of the various official documents and assisted citizens with their participation in the public consultation. ${ }^{155}$ In spite of Europe's fragmented linguistic landscape and through a colourful campaign, they managed to attract considerable media attention, motivate thousands of websites to protest ${ }^{156}$ and mobilise a sizeable number of citizens to directly communicate with the telecom regulators. BEREC explained that the received comments provided the regulators with valuable feedback from stakeholders and increased transparency. ${ }^{157}$ It is remarkable

\footnotetext{
150 See $\mathrm{n} 102$ and accompanying text.

151 Gerlach (n 149) 178, 249-50.

152 See Thomas Lohninger, 'How we saved the Internet', Save the Internet (4 October 2016), online: $<$ https://epicenter.works/content/how-we-saved-the-internet-in-europe>.

153 See public consultation on the draft BEREC Guidelines on the Implementation by National Regulators of European Net Neutrality rules, online: <http://berec.europa.eu/eng/news_consultations/Closed_ Public_Consultations/2016/>.

154 Ibid.

155 See Lohninger (n 152).

156 See Vlad Dudau, '7000 EU websites are protesting net neutrality loopholes, with "EU Slowdown" campaign', Neowin (28 June 2016), online: <www.neowin.net/news/7000-eu-websites-are-protesting-netneutrality-loopholes-with-eu-slowdown-campaign $>$.

157 See the presentation at the BEREC net neutrality guidelines press conference of 30 August 2016, online: $<$ http://berec.europa.eu/eng/document_register/subject_matter/berec/others/6166-presentation-atthe-net-neutrality-guidelines-press-conference>.
} 
that the final guidelines provide clarification on some of the critical provisions that had only been vaguely defined in the Regulation. Accordingly, Internet providers are barred from commercial blocking or throttling of services aside from reasonably managing their networks, such as to avoid congestion. Zero rating is to be permitted only within narrow limits. With respect to specialised services (ie services that are optimised for specific content, applications or services), the final guidelines specify that these can only be used for services that have nothing to do with Internet access, and cannot be misused to sell preferential treatment of regular Internet services. ${ }^{158}$

The chronicle of the net neutrality debate in the EU shows how activistdriven mobilisation of wide segments of civil society can enhance a public debate on emerging societal values. However, I would hasten to add that spontaneous processes of constitutionalisation cannot replace democratically legitimised legislation or constitutional amendment. Rather, the formal and the social constitution should be seen as interconnected vessels. The formal constitution will be the benchmark for evaluating the democratic quality of bottom-up constitutional processes. Hence, there is a reflexive relationship between the two types of constitution. The formal national constitution will continue to be the ultimate point of reference for the channelling of issues related to the distinction and interrelation between law and politics at the national level, ${ }^{159}$ while spontaneous processes of societal constitutionalism develop bottom-up from local cultures. Although these cultures are rooted locally, their horizon is global. The Internet has made the world an interconnected whole and ultimately fulfilled McLuhan's 1962 prophecy of the 'global village', where he argues that 'the electro-magnetic discoveries have recreated the simultaneous "field" in all human affairs so that the human family now exists under conditions of a "global village". ${ }^{160}$

Concluding, cultural practices will emerge from interaction between parties with a local basis and a global horizon of communication. ${ }^{161}$ If net neutrality becomes the subject of such communication, the code of the economic system will be used and normative expectations regarding net neutrality will develop within the economic system. As described above, the norm

\footnotetext{
158 See the BEREC Guidelines on the Implementation by National Regulators of European Net Neutrality Rules, BoR (16) 127, August 2016, at paras 40-48 and 99-127, online: <http://berec.europa.eu/eng/ document_register/subject_matter/berec/regulatory_best_practices/guidelines/6160-berecguidelines-on-the-implementation-by-national-regulators-of-european-net-neutrality-rules $>$.

159 Luhmann (n 30) 357-80; see also Jürgen Habermas, Between Facts and Norms: Contributions to a Discourse Theory of Law and Democracy, translated by William Rehg (MIT Press, 1996) 238-86.

160 Marshall McLuhan, The Gutenberg Galaxy: The Making of Typographic Man (University of Toronto Press, 2011 [1962]) 36. Two years later he wrote in Understanding Media: 'As electronically contracted, the globe is no more than a village. Electric speed in bringing all social and political functions together in a sudden implosion has heightened human awareness of responsibility to an intense degree'. Marshall McLuhan, Understanding Media: The Extensions of Man (MIT Press, 1994 [1964]) 5.

${ }^{161}$ According to Luhmann, three types of social systems need to be distinguished: interaction, organisations and society. See Luhmann (n 124) 2, 15.
} 
production emerging from the spontaneous sphere will be competing with expectations that are being formed within the organised professional sphere of the economic system. This reflexive process of norm production will be followed by the second stage of the constitutionalisation process where the normative expectations emerging from the economic system will be juridified in a structural coupling with the legal system. Depending on the case at issue, concrete norms will be produced at the level of national, international or transnational law. In the case of the US debate, juridification of net neutrality is mainly being channelled through national law-based litigation procedures and will result in decisions of the national courts. When constitutional questions arise, the point of reference for the courts will be the specific national (formal) constitution. ${ }^{162}$ In the EU, in addition to national constitutional processes, the ECtHR and the CJEU will play an important role at the international or supranational level of constitutionalisation. Because of the leading position of the US-American Internet platforms, the net neutrality debate in the United States has an important signalling effect on constitutionalisation processes in other countries and will impact the speed of the principle's universalisation. ${ }^{163}$

\section{Acknowledgements}

The author would like to thank Ulrike Babusiaux, Giovanni Biaggini, Andreas Kley, Matthias Mahlmann, Frank Meyer, Johannes Reich and Gunther Teubner for comments on an earlier version of this text, and Yannick Weber for research assistance.

\section{Disclosure statement}

No potential conflict of interest was reported by the author.

\section{Funding}

This work was supported by the Universität Zürich.

\footnotetext{
${ }^{162}$ For a media theory-based account of the relationship between sectoral societal constitutions and the national (formal) constitution see Thomas Vesting, Computernetzwerke, Die Medien des Rechts, vol 4, (Velbrück Wissenschaft, 2015) 110-25.

163 Timothy Garton Ash, Free Speech (Yale University Press, 2016) 357-60.
} 